\title{
RELATIONSHIP BETWEEN THE ADSORPTION CAPACITY OF PESTICIDES BY WOOD RESIDUES AND THE PROPERTIES OF WOODS AND PESTICIDES
}

\author{
SONIA RODRIGUEZ-CRUZ, MARIA S. ANDRADES ${ }^{1}$, MARIA SANCHEZ- \\ CAMAZANO, MARIA J. SANCHEZ-MARTIN* \\ Instituto de Recursos Naturales y Agrobiología, CSIC. Apdo. 257. \\ 37071 Salamanca. Spain \\ ${ }^{1}$ Dpto Agricultura y Alimentación. Universidad de La Rioja. Madre de Dios, 51. \\ 26006 Logroño. Spain
}

Pages: 5

Figures: 1

Tables: 4 


\section{TABLE S-1. Determination of the wood characteristics}

$\begin{array}{ll}\begin{array}{l}\text { Parameter } \\ \text { Total C }\end{array} & \begin{array}{l}\text { Method } \\ \text { Automatic carbon analyser Wösthoff Carmograph 12H Omega } \\ \text { (Bochum, Germany) }\end{array} \\ \text { Soluble C } & \text { Carbon analyzer Shimadzu 5050 (Shimadzu, Columbia, MD). } \\ \text { CEC } & \text { Ammonium acetate method } \\ \text { Surface area } & \begin{array}{l}\mathrm{N}_{2} \text { adsorption-desorption method at }-196^{\circ} \mathrm{C} \text { on an Micromeritics } \\ \text { Gemini analyzer (Norcross, USA) }\end{array} \\ \text { Lignin content } & \text { UNE 57100:1986 regulation }\end{array}$

\begin{tabular}{|c|c|c|c|c|c|}
\hline $\begin{array}{c}\text { Common } \\
\text { name }\end{array}$ & Chemical name & $\begin{array}{l}\text { Water } \\
\text { solubility } \\
\quad(g / L)\end{array}$ & $\begin{array}{c}\log \\
\text { Kow }^{\mathrm{a}}\end{array}$ & $\begin{array}{c}\text { Concentration } \\
(\mu \mathrm{b} / \mathrm{mL})\end{array}$ & $\begin{array}{l}\text { Pesticide } \\
\text { analysis }\end{array}$ \\
\hline Linuron & $\begin{array}{l}\text { 3-(3,4-Dichlorophenyl)-1- } \\
\text { methoxy-1-methylurea }\end{array}$ & 0.081 & 3.00 & $1-25$ & $\mathrm{LSC}^{\mathrm{c}}$ \\
\hline Alachlor & $\begin{array}{l}\text { 2-Chloro-2',6'-diethyl-N- } \\
\text { methoxymethyl } \\
\text { acetanilide }\end{array}$ & 0.24 & 2.63 & $1-25$ & $\mathrm{LSC}^{\mathrm{c}}$ \\
\hline $\begin{array}{l}\text { Metalaxy } \\
1\end{array}$ & $\begin{array}{l}\text { Methyl N-(2,6- } \\
\text { dimethylphenyl)-N- } \\
\text { (methoxyacetyl)-DL alaninate }\end{array}$ & 8.40 & 1.75 & $1-25$ & $\mathrm{LSC}^{\mathrm{c}}$ \\
\hline $\begin{array}{l}\text { Chlorpyri } \\
\text { fos }\end{array}$ & $\begin{array}{l}\text { O,O-diethyl O- }(3,5,6- \\
\text { trichloro-2-pyridyl } \\
\text { phosphorothioate }\end{array}$ & 0.002 & 4.70 & $0.2-1$ & HPLC-MS $^{\mathrm{d}}$ \\
\hline Dicamba & 3,6-dichloro-o-anisic acid & 6.50 & -0.55 & $50-300$ & HPLC-MS $^{\mathrm{d}}$ \\
\hline Paraquat & $\begin{array}{l}\text { 1,1'-dimethyl-4,4'- } \\
\text { bipyridylium dichloride }\end{array}$ & 620 & -4.5 & $50-300$ & $U^{\mathrm{e}}$ \\
\hline
\end{tabular}

${ }^{\mathrm{a} O c t a n o l} /$ water distribution coefficient. ${ }^{\mathrm{b}}$ Concentration range used in the adsorption study for different pesticides. ${ }^{\mathrm{c}}$ Liquid Scintillation Counter. ${ }^{\mathrm{d}}$ High Performance Liquid Chromatography with Mass Spectrometry (Chromatographic conditions: A Waters Symmetry C18 column (75 x $4.6 \mathrm{~mm}$ I.D., $3.5 \mu \mathrm{m})$ was used at ambient temperature. The mobile phase was $85 \%$ acetonitrile and $15 \%$ water with $0.1 \%$ of formic acid for chlorpyrifos and $65 \%$ acetonitrile-water $(60: 40)$ with $0.5 \%$ acetic acid, $10 \%$ methanol and $25 \%$ water with $0.1 \%$ of formic acid for dicamba. Flow rate of mobile phase was $0.5 \mathrm{~mL} / \mathrm{min}$ and sample injection volume was $10 \mu \mathrm{l}$. Retention times were $5 \pm 0.5 \mathrm{~min}$ and $7.5 \pm 1$ min for chlorpyrifos and dicamba, respectively. Detection by HPLC/DAD was at $229 \mathrm{~nm}$ for chlorpyrifos and $280 \mathrm{~nm}$ for dicamba, and detection with HPLC/MS to confirm the identity of these compounds was carried out by monitoring the positive molecular ion $(\mathrm{m} / \mathrm{z}) 197$ for chlorpyrifos, and 175 for dicamba). ${ }^{\mathrm{e}}$ Ultraviolet spectroscopy, $\lambda=255 \mathrm{~nm}$. All UV determinations were carried out against a wood blank to correct for possible interferences in the measurement of the pesticide. 
TABLE S-3. Adsorption coefficients of studied pesticides by different organic and inorganic materials

\begin{tabular}{|c|c|c|c|c|c|}
\hline Adsorbent & Linuron & Alachlor & Metalaxyl & Chlorpyrifos & Source \\
\hline Wood sawdust & $74.4-123$ & $22.4-48.8$ & $4.95-10.95$ & $3176-6559$ & This study \\
\hline Clays & $2.36-9.91^{\mathrm{a}}$ & $22.4-33.8^{\mathrm{a}}$ & $0.05-2.49^{\mathrm{a}}$ & $529-968^{b}$ & $\begin{array}{l}{ }^{\mathrm{a}} \operatorname{Ref}(16) \\
{ }^{\mathrm{b}} \operatorname{Ref}(33)\end{array}$ \\
\hline Soils & $\begin{array}{l}1.60-5.32^{c} \\
2.29-2.36^{d}\end{array}$ & $\begin{array}{l}3.29-5.90^{c} \\
0.77-0.94^{d}\end{array}$ & $0.13-0.68^{c}$ & $131-272^{b}$ & $\begin{array}{l}{ }^{\mathrm{c}} \operatorname{Ref}(17) \\
{ }^{\mathrm{d}} \operatorname{Ref}(14)\end{array}$ \\
\hline Amended Soils & $\begin{array}{l}4.70-16.0^{\mathrm{e}} \\
2.97-4.02^{\mathrm{d}}\end{array}$ & $0.97-2.94^{\mathrm{d}}$ & $\begin{array}{l}0.49-5.42^{f} \\
0.44-2.05^{\mathrm{g}}\end{array}$ & - & $\begin{array}{l}{ }^{\mathrm{e}} \operatorname{Ref}(15,34) \\
{ }^{\mathrm{f}} \operatorname{Ref}(35) \\
{ }^{\mathrm{g}} \operatorname{Ref}(13)\end{array}$ \\
\hline Humic Acid & 227 & 97.5 & 27.6 & 3239 & $\operatorname{Ref}(36)$ \\
\hline Organo clays & $174-1454$ & $137-546$ & $2.12-191$ & - & $\operatorname{Ref}(16)$ \\
\hline Organo soils & $54.3-325$ & $22.1-79.5$ & $4.10-43.3$ & - & Ref (17) \\
\hline
\end{tabular}

TABLE S-4. Freundlich adsorption coefficients (Kf and $\mathrm{nf}$ ) of linuron and metalaxyl by pine and oak woods washed

\begin{tabular}{|c|c|c|c|c|c|c|}
\hline \multirow{2}{*}{$\begin{array}{l}\text { Pesticide/ } \\
\text { parameter }\end{array}$} & \multicolumn{3}{|c|}{ Pine } & \multicolumn{3}{|c|}{ Oak } \\
\hline & Water & HCl & $\mathrm{NaOH}$ & Water & HCl & $\mathrm{NaOH}$ \\
\hline \multicolumn{7}{|l|}{ Linuron } \\
\hline $\mathrm{Kf}$ & $99.7 \pm 0.70^{\mathrm{a}}$ & $155 \pm 0.50$ & $92.2 \pm 1.57$ & $85.6 \pm 0.05$ & $165 \pm 27.1$ & $137 \pm 23.8$ \\
\hline $\mathrm{nf}$ & $0.95 \pm 0.02$ & $0.91 \pm 0.01$ & $0.91 \pm 0.01$ & $0.95 \pm 0.03$ & $0.70 \pm 0.01$ & $0.69 \pm 0.04$ \\
\hline \multicolumn{7}{|l|}{ Metalaxyl } \\
\hline $\mathrm{Kf}$ & $11.9 \pm 0.75$ & $18.0 \pm 0.19$ & $12.2 \pm 0.11$ & $6.49 \pm 0.51$ & $9.39 \pm 0.51$ & $6.56 \pm 0.36$ \\
\hline $\mathrm{nf}$ & $0.81 \pm 0.03$ & $0.92 \pm 0.01$ & $0.90 \pm 0.01$ & $1.02 \pm 0.03$ & $0.94 \pm 0.03$ & $0.93 \pm 0.01$ \\
\hline
\end{tabular}




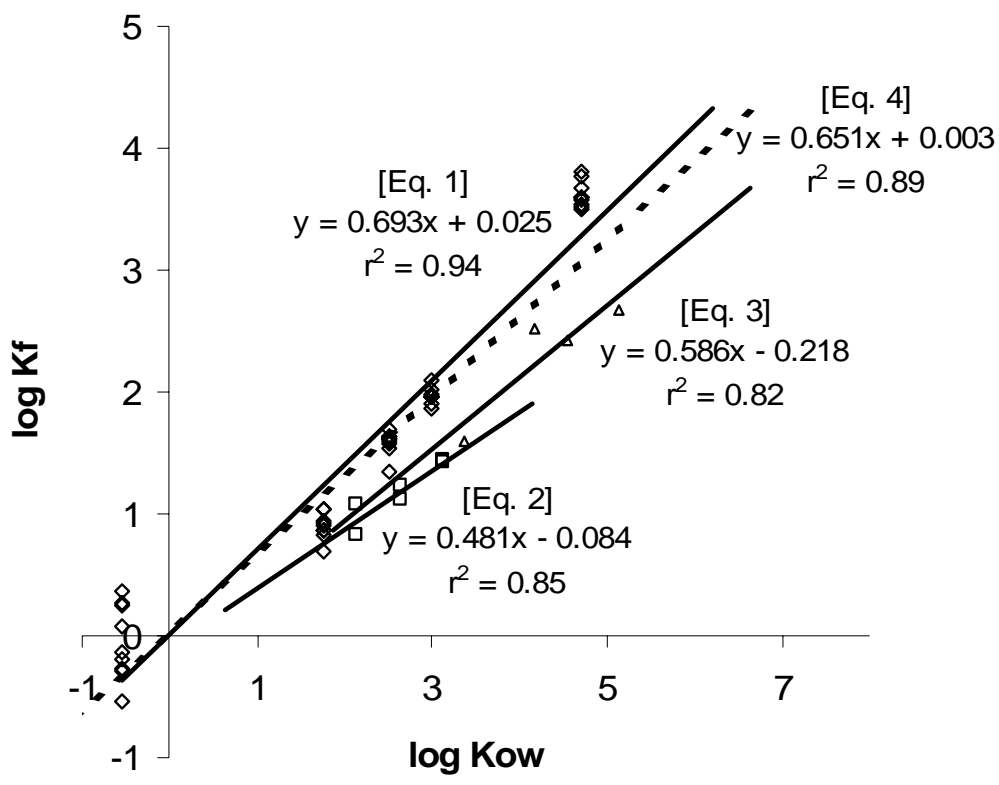

Figure S-1. Regression lines from data of this study [Eq. 1], of Mackay and Gschwend (28) [Eq. 2] and of Boving and Zang (30) [Eq. 3], and regression line obtained from all data together considered [Eq. 4]

\section{References}

(13) Andrades, M. S.; Rodríguez-Cruz, M. S.; Sánchez-Martín, M. J.; SánchezCamazano, M. Effect of the addition of wine distillery wastes to vineyard soils on the adsorption and mobility of fungicides. J. Agric. Food Chem. 2004, 52, 30223029.

(14) Dorado, J.; López-Fando, C.; Zancada, M.C.; Almendros, G. Sorption-desorption of alachlor and linuron in a semiarid soil as influenced by organic matter properties after 16 years of periodic inputs. J. Agric. Food Chem. 2005, 53, 5359-5365.

(15) Iglesias-Jiménez, E.; Poveda, E.; Sánchez-Martín, M. J.; Sánchez-Camazano, M. Effect of the nature of exogenous organic matter on pesticide adsorption by the soil. Arch. Environ. Contam. Toxicol. 1997, 33, 127-134. 
(16) Sánchez-Martín, M. J.; Rodríguez-Cruz, M. S.; Andrades, M. S.; SánchezCamazano, M. Efficiency of different clay minerals modified with a cationic surfactant in the adsorption of pesticides. Influence of clay type and pesticide hydrophobicity. Appl. Clay Sci. 2006, 31, 216-228.

(17) Rodriguez-Cruz, M. S.; Sánchez-Martín, M. J.; Andrades, M. S. SánchezCamazano, M. Comparison of pesticide sorption by physicochemically modified soils with natural soils as a function of soil properties and pesticide hydrophobicity. Soil Sediment Contam. 2006, 15, 401-415.

(28) MacKay A. A.; Gschwend, P. M. Sorption of monoaromatic hydrocarbons to wood. Environ. Sci. Technol. 2000, 34, 839-845.

(30) Boving, T. B.; Zhang, W. Removal of aqueous-phase polynuclear aromatic hydrocarbons using aspen wood fibers. Chemosphere 2004, 54, 831-839.

(33) Rodríguez-Cruz, S.; Aatouf, N.; Draoui, K.; Del Hoyo, C.; Sánchez-Martín, M. J. Adsorción de cloropirifos por minerales de la arcilla y suelos de Marruecos en sistema acuoso. Macla 2006, 6, 399-402.

(34) Rodríguez-Cruz, M. S.; Andrades, M. S.; Sánchez-Martín, M. J.; SánchezCamazano. M. Efecto de la aplicación de lodos de aguas residuales al suelo en la persistencia del herbicida linuron en condiciones de campo. In Estudios de la zona no saturada del suelo Vol. VI.; Alvarez-Benedi, J., Marinero, P., Eds.; ITACYL: Valladolid, Spain, 2003; pp. 349-354.

(35) Cox, L.; Fernandes, M. C.; Zsolnay, A.; Hermosin, M. C.; Cornejo, J. Changes in dissolved organic carbon of soil amendments with aging: Effect on pesticide adsorption behaviour. J. Agric. Food Chem. 2004, 52, 5635-5642.

(36) Valderrábano, M.; Rodríguez-Cruz, M. S.; del Hoyo, M. C. Sánchez-Martín, M. J. Physicochemical study of the adsorption of pesticides by wood components. In Bioavailability of pollutants and soil remediation; Ortega-Calvo J. J. Ed.; IRNASE, CSIC, Sevilla, Spain, 2006; pp 35. 